\title{
Estimating Intake and Digestibility of Native Flint Hills Hay
}

\section{RAMA RAO, LENIEL H. HARBERS, AND ED F. SMITH}

Highlight: In vivo and in vitro studies were conducted on native hay from the Flint Hills harvested at three stages of maturity from an area annually burned in late spring. Intake and digestibility declined with stage of maturity. In vivo organic matter intake and digestibility was satisfactorily estimated using fecal nitrogen and fecal organic matter output data as independent variables. $A$ somewhat less reliable estimate of digestibility was provided by in vitro fermentation.

The Flint Hills of Kansas form a unique rangeland area of approximately 1.8 million hectares. It is used for continuous grazing by beef cows and for summer grazing by steers. Further improvement in production would be likely with estimations of intake and nutrient digestibilities of native pastures. A series of studies was therefore conducted to establish prediction equations for organic matter digestibility and intake from esophageally collected samples and fecal residue. The results obtained using hay harvested at different stages of maturity are presented in this report.

\section{Methods}

Native hay was harvested during June, July, and September, 1971 , from an area burned annually in late spring. Harvested hay was allowed to sun dry for 2 days, then was baled and stored indoors until used.

Two groups of six yearling Angus steers (average weight, $272 \mathrm{~kg}$ ) were used in four metabolism trials in a randomized incomplete block design. For 10 days prior to a 7-day collection period, the steers were maintained on hay (amount offered daily being equivalent to $2.50 \%$ of body weight). Mineralized salt blocks and water were readily accessible.

Four esophageal samples from each hay were collected at

The authors are research assistant, associate professor, and professor of animal science, Kansas State University, Manhattan. Rao at present is assistant research officer, Andhra Pradesh Agricultural University, Livestock Research Station, Rajendranagar, Hyderabad 50030.

The research is contribution No.433, Department of Animal Science and Industry, Kansas Agricultural Experiment Station, Kansas State University, Manhattan. It was supported in part by contract fund AID (Nesa-146).

Manuscript received February 10, 1973.

four different times, two replications on each of four occasions. Simultaneously, a sample from each cutting of hay was hand picked for the control. Samples were frozen immediately and stored until analyzed.

Feed and fecal samples were dried in a forced-air oven at $50^{\circ} \mathrm{C}$ for $72 \mathrm{hr}$ for proximate analyses (A.O.A.C., 1970); those used for cell-wall constituents were dried in acetone according to Goering and Van Soest (1970).

For in vitro studies, we used the two-stage, 24-hour fermentation method of Tilley and Terry (1963). Inoculum was obtained from two ruminally fistulated Hercford steers maintained on a mixture of prairie and alfalfa hays plus $2.0 \mathrm{lb}$ of a $16 \%$ protein concentrate with minerals. In vitro dry matter digestibilities of esophageally and hand sampled hays were comparcd to in vivo digestibilities determined from total collection. In vitro digestibility values of esophageal samples were used to establish a regression for estimating in vivo dry matter digestibility of the three individual hays.

Data were subjected to least squares analyses of Harvey (1960). Duncan's new multiple range test was used to separate significant differences among means (Steel and Torrie, 1960). Regression analyses were obtained by a stepwise deletion procedure described by Draper and Smith (1966). Data differing at the $5 \%$ level of probability have been considered significant.

\section{Results and Discussion}

Crude protein, ash, crude fiber, and nitrogen-free extract values for esophageally collected hay samples were different from those for the hand-picked samples: crude protein and ash were higher; crude fiber and nitrogen-free extract lower (Table 1). There was no difference resulting from frequency of collection; nor was there any sample $x$ time interaction.

A threefold increase in phosphorus and decreased calcium were observed in esophageal collections. Phosphorus in fistulae samples is increased significantly by salivary contamination (Lesperance et al., 1960); excessive saliva removal may decrease calcium content (Ansotegin et al., 1971).

Digestibility and Intake

Dry and organic matter intakes for the three hays declined 
Table 1. Means and standard errors of chemical composition (\%) of native hays cut at three growth stages.

\begin{tabular}{lcccccc}
\hline \hline $\begin{array}{l}\text { Time and } \\
\text { collection } \\
\text { method }\end{array}$ & Ash protein fiber & $\begin{array}{c}\text { Crude } \\
\text { extract }\end{array}$ & Calcium & $\begin{array}{c}\text { Phos- } \\
\text { phorus }\end{array}$ \\
\hline Hay harvest time & & & & & & \\
June & $7.7^{\mathrm{a}, 2}$ & $5.8^{\mathrm{a}}$ & $33.0^{\mathrm{a}}$ & $45.9^{\mathrm{a}}$ & $0.4^{\mathrm{c}}$ & $0.2^{\mathrm{a}}$ \\
July & $7.4^{\mathrm{a}}$ & $4.8^{\mathrm{b}}$ & $34.8^{\mathrm{b}}$ & $45.7^{\mathrm{a}}$ & $0.3^{\mathrm{a}}$ & $0.2^{\mathrm{a}}$ \\
September & $8.9^{\mathrm{b}}$ & $3.8^{\mathrm{b}}$ & $33.0^{\mathrm{a}}$ & $46.6^{\mathrm{a}}$ & $0.3^{\mathrm{a}}$ & $0.2^{\mathrm{a}}$ \\
S. E. & 0.22 & 0.19 & 0.38 & 0.48 & 0.03 & 0.02 \\
Sample collection & $\begin{array}{c}1 \\
\text { method }\end{array}$ & & & & & \\
$\quad$ Esophageal & $9.3^{\mathrm{c}}$ & $5.1^{\mathrm{c}}$ & $32.8^{\mathrm{a}}$ & $44.8^{\mathrm{a}}$ & $0.2^{\mathrm{b}}$ & $0.3^{\mathrm{b}}$ \\
Handpicked & $6.7^{\mathrm{a}}$ & $4.4^{\mathrm{b}}$ & $34.4^{\mathrm{b}}$ & $47.3^{\mathrm{b}}$ & $0.4^{\mathrm{c}}$ & $0.1^{\mathrm{c}}$ \\
S. E. & .18 & .16 & .31 & .40 & .02 & .02 \\
\hline
\end{tabular}

${ }^{1}$ Standard error.

${ }^{2}$ Means in the same column followed by the same letter are not significantly different at the $5 \%$ probability level as determined by Duncan's new multiple range test.

gradually (Table 2). Consumption of June hay was significantly greater than that of September hay, indicating, as Heaney (1969) has suggested, that as a plant matures it has a depressing effect on voluntary intake.

Digestibility of nutrients usually decreased more between hays cut in June and July than they did between hays cut in July and September (Table 2). Crude protein and acid detergent fiber digestibilities in September hay were each about 20 units lower than for June hay (Fig. 1). Their relative digestibilities seemed a good indicator of the quality of those native hays.

\section{In Vivo vs In Vitro Digestibility}

In vitro digestibility of hand-picked samples was lower than that of esophageal samples (Fig. 2). In hand-picked samples, the in vitro digestibility of July hay was 2 or 3 units higher than that of June or September hay. In esophageally collected samples, in vitro digestibility of July and September hay was the same: the June sample was 4 units higher.

The correlation coefficient between in vivo and esophageal in vitro dry matter digestibility was 0.77 . The simple regression equation gave this value:

$\hat{\mathrm{Y}}=-47.86+2.05$ (IVDMD), where

$\hat{\mathrm{Y}}=$ Estimated dry matter digestibility $(\%)$

IVDMD = In vitro dry matter digestibility $(\%)$

A collaborative study using good quality hay indicated that in vitro dry matter digestibility values ranged from 57.1 to $64.2 \%$ with correlation cocfficients from 0.79 to 0.97 (Barnes, 1969). In our studies dry matter intake was low, resulting in high in vivo digestibility. Nutritive value indexes for these hays harvested in June, July, and September were 43.48, 35.05, and 28.35 , respectively (standard forage value-70.00).

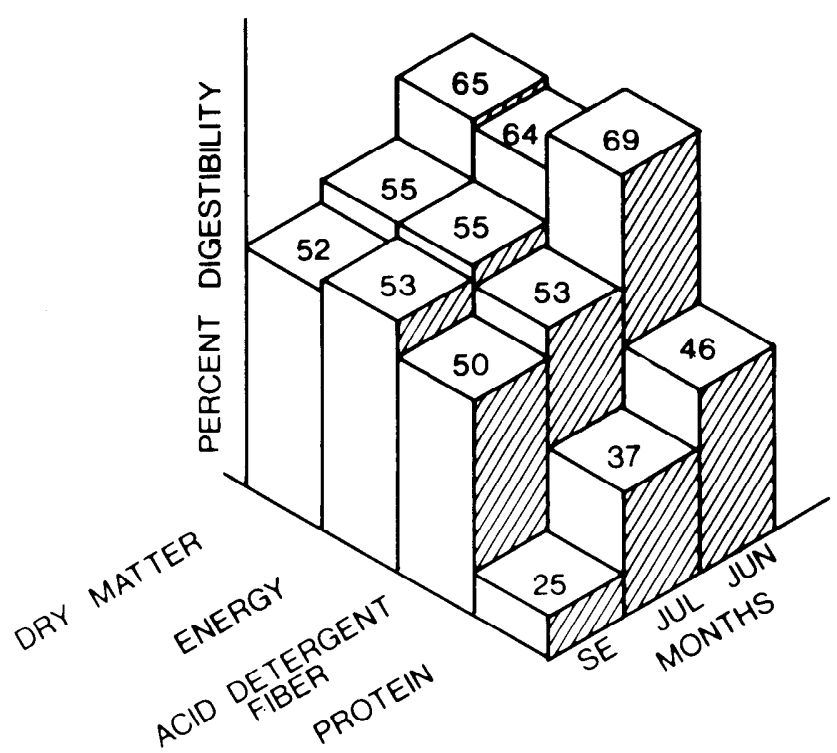

Fig. 1. Comparison of in vivo digestibility of dry matter, energy, acid detergent fiber, and crude protein of native hay harvested at three stages of maturity.

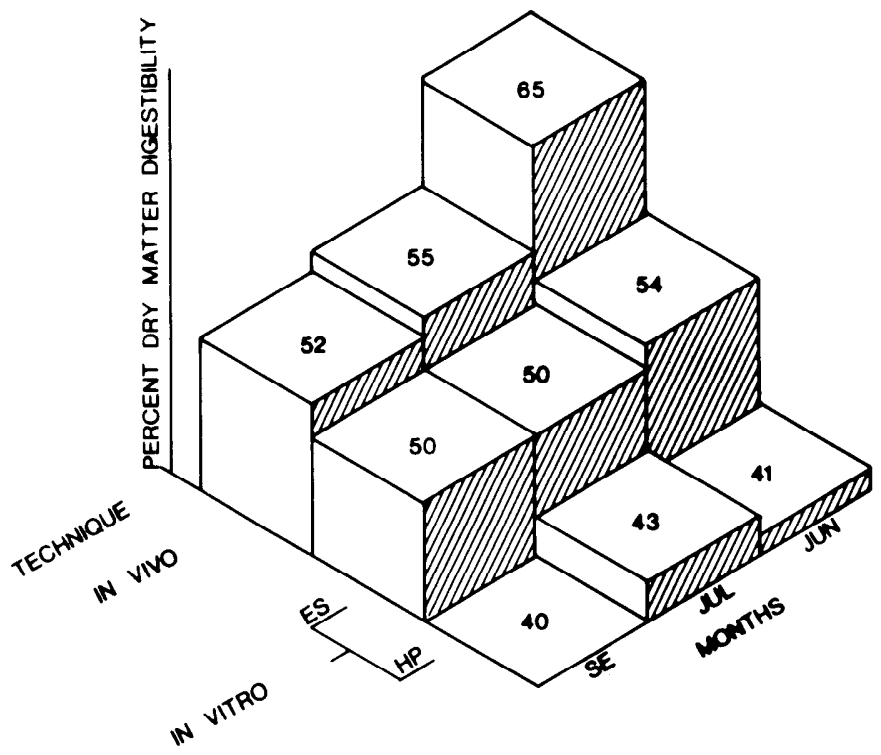

Fig. 2. Comparison of in vivo and in vitro (ES = esophageal samples; $H P=$ handpicked samples) digestion of native hay dry matter at three stages of maturity.

Table 2. Means of herbage intake (kg) and digestibility coefficients $(\%)$ of hays cut at three growth stages. ${ }^{1}$

\begin{tabular}{|c|c|c|c|c|c|c|c|}
\hline \multirow[b]{2}{*}{ Date } & \multicolumn{2}{|c|}{ Intake } & \multicolumn{5}{|c|}{ Digestibility coefficients } \\
\hline & $\begin{array}{c}\text { Dry } \\
\text { matter }\end{array}$ & $\begin{array}{c}\text { Organic } \\
\text { matter }\end{array}$ & $\begin{array}{l}\text { Crude } \\
\text { fiber }\end{array}$ & $\begin{array}{l}\text { Nitrogen } \\
\text { free } \\
\text { extract }\end{array}$ & $\begin{array}{c}\text { Neutral } \\
\text { detergent } \\
\text { fiber }\end{array}$ & $\begin{array}{c}\text { Hemi- } \\
\text { cellulose }\end{array}$ & Cellulose \\
\hline \multicolumn{8}{|l|}{ Hay harvest time } \\
\hline June & $5.7^{\mathrm{a}, 2}$ & $5.3^{\mathrm{a}}$ & $70.9^{\mathrm{a}}$ & $69.4^{\mathrm{a}}$ & $70.9^{\mathrm{a}}$ & $76.8^{\mathrm{a}}$ & $70.1^{\mathrm{a}}$ \\
\hline July & $5.3^{\mathrm{a}}$ & $4.9^{\mathrm{a}}$ & $65.1^{\mathrm{b}}$ & $56.4^{\mathrm{b}}$ & $59.0^{\mathrm{b}}$ & $70.4^{b}$ & $60.6^{\mathrm{b}}$ \\
\hline September & $4.2^{\mathrm{b}}$ & $3.8^{\mathrm{b}}$ & $59.2^{\mathrm{c}}$ & $59.3^{\mathrm{b}}$ & $53.8^{\mathrm{c}}$ & $68.3^{b}$ & $62.0^{\mathrm{b}}$ \\
\hline
\end{tabular}

\footnotetext{
${ }^{1}$ Each value for date of cut represents an average of six replications.

${ }^{2}$ Means in the same column followed by the same letter are not significantly different at the $5 \%$ probability as determined by Duncan's new multiple range test.
} 
